\title{
Top trends in academic libraries A review of the trends and issues affecting academic libraries in higher education
}

E very other year, the ACRL Research Planning and Review Committee produces a document on top trends in academic libraries. This year, after numerous discussions and literature reviews, the committee decided upon a unifying theme for current trends: deeper collaboration. The committee found examples of either recent library collaborations or current collaborations within higher education that we believe could benefit from library participation. We focus on the following large categories within higher education: data, device neutral digital services, evolving openness in higher education, student success initiatives, competency-based learning, altmetrics, and digital humanities.

\section{Data}

New initiatives and collaborative opportunities Libraries, IT, research administration, and grant support will have to collaborate to find the expertise necessary to provide data management support through the research process. Analyzing the data needs of researchers across institutional domains may require the library to identify and connect researchers across formal and informal functional units for sharing, analyzing, and reusing data.

Increased emphasis on open data, dataplan management, and "big data" research are creating the impetus for academic institutions from colleges to research universities to develop and deploy new initiatives, service units, and resources to meet scholarly needs at various stages of the research process. Institutions providing data-related services exist along a continuum of light-to-heavy involvement, while funding organizations, academic institutions, researchers, and librarians continue to struggle towards a shared vocabulary with commonly understood definitions and to develop strategies to support these new initiatives.

Universities are rolling out graduate and certificate programs to prepare professionals for careers related to the analysis and manipulation of big data. Programs such as the Institute for Advanced Analytics at North Carolina State University ${ }^{1}$ and the graduate certificate in data mining offered by Stanford University ${ }^{2}$ place new demands on libraries for cross-disciplinary expertise in data collection access, metadata, curation, and preservation. For example, the iSchool at Syracuse University ${ }^{3}$ and the University of California-Berkeley School of Information ${ }^{4}$ provide specific training for librarians and other information professionals in the use of complex data.

Cooperative roles for researchers, repositories, and journal publishers

Repositories such as Dryad, which stores data associated with specific publications, provide discovery and access options for researchers to locate data for verification, scrutiny, re-use, and citation in new scholarly endeavors. FigShare, ${ }^{5}$ which is discipline and format agnostic, provides free private 
and public storage space for data that may not necessarily be associated with publication and may in fact have been deemed useless for the original research project. The discovery and re-use of small and large data sets require high-quality metadata and curation and libraries are uniquely positioned to provide this expertise. ${ }^{6}$

Journal publishers, such as BioMed Centrall $^{7}$ and PLOS, ${ }^{8}$ now require authors to make underlying data for published articles available to readers. This will continue to place more data in the open domain for sharing and will allow data cited in peer-reviewed publications to be re-used and analyzed more efficiently. This may create new challenges to librarians as issues related to attribution, citation, and unique identifiers will multiply around data sets, figures, images, etc.

\section{Partnerships related to discovery and re-use of data}

Journal publishers and aggregators are also coming under pressure to make their content available for large-scale text mining and harvesting projects. In February, Elsevier removed most barriers to researchers so that data could be extracted from a huge number of articles. ${ }^{9}$ While this provides new research opportunities, it may also bring renewed pressure on library budgets to provide access to "big" journal packages to support these types of data-harvesting investigations.

Web-based tools to manipulate, clean, and transform data are emerging, as well. OpenRefine,${ }^{10}$ formerly Google Refine, is an open source project that will allow researchers to locate, scrub, and connect to data sets and re-use data for new purposes. Librarians may find this a useful tool not only in terms of assisting researchers, but also for manipulating and using data gathered within their own institutions.

\section{Device neutral digital services}

The mobile device market expanded and diversified over the last two years with an increasing number of providers and screen dimensions. In January 2014, the Pew Re- search Center reported over $42 \%$ of U.S. adults own a tablet (up 8\% from just four months earlier). ${ }^{11}$

Further, the 2013 ECAR study emphasized high student expectations for mobile access to materials and the importance of all things "device" to be neutral, ${ }^{12}$ while the Horizon Report, after including tablets on the "one year or less" adoption horizon for the past two years, has stopped listing them in the most recent 2014 report. ${ }^{13}$ It is no longer enough for libraries and their partners to design digital services for only desktops or mobile phones.

A solution growing in popularity is responsive design, which facilitates having only one website that automatically adapts to the size of a visitor's screen. Many universities and colleges (e.g., Dartmouth University, ${ }^{14}$ Earlham College, ${ }^{15}$ and the University of Michigan ${ }^{16}$ ) are already moving to responsive design for their web presences, so this trend presents an area of opportunity to collaborate with overarching web services departments and perhaps even take the lead. Library websites using responsive design include Grand Valley State University Libraries, ${ }^{17}$ University of Toronto's Library Catalogue, ${ }^{18}$ Princeton University Library, ${ }^{19}$ and University of Arizona's Special Collections. ${ }^{20}$

There will also be growing hope for database and other platform vendors to offer device neutral solutions, as most currently only offer mobile sites and/or apps. Breaking this trend is OCLC, who will launch a new WorldCat Discovery interface (merging WorldCat Local and First Search and offering a link resolver) in 2014 that adjusts to any screen size. ${ }^{21}$ Academic librarians must advocate and collaborate with vendors for seamless design that works for all screen sizes.

\section{Evolving openness in higher education}

Open access

There continue to be significant efforts to support and incentivize open access to research $^{22}$ and to the benefits of higher education more generally. 
Following the National Institutes of Health and National Science Foundation mandates for open access to research, there is further emphasis on national legislative and executive activity to promote open access to taxpayer-funded research outputs, including data, articles, and educational resources.

For example, the Omnibus Appropriations Bill requires certain agencies to provide timely online access to funded articles. In addition, draft public access policy plans from the Office of Science, Technology, and Policy will be made available in early 2014. Other current, relevant legislation, such as the Fair Access to Science and Technology Research Act, would "codify" public access to federally funded research. This flurry of activity suggests that there is continued interest in formalizing, funding, and coordinating public access efforts.

Academic libraries and their institutions continue to support open access publishing through the implementation of institutionalwide open access mandates evidenced by the Coalition of Open Access Policy Institutions ${ }^{23}$ and through entering into agreements to pay or reimburse open access publisher fees to faculty. The Compact for Open-Access "supports equity in business models used for scholarly publishing" by committing each university to "the timely establishment of durable mechanisms for underwriting reasonable publication charges for [open access] articles." ${ }^{24}$

\section{Open education}

In addition to supporting payment or reimbursement for open access publishing fees, academic libraries are beginning to provide financial support for and promotion of open educational resources (OERs). Two examples are the Oregon State University Libraries and Press Open Textbook Initiative ${ }^{25}$ and the Open Alternative Textbook Initiative at Kansas State University. ${ }^{26}$ Other collaborative publishing funding models are developing in the area of academic monographs and imprints, e.g., Knowledge Unlatched, which "depends on many libraries from around the world sharing the payment of a single Title Fee to a publisher, in return for a book being made available on a Creative Commons license." 27

Other OERs could possibly benefit from library participation, massive open online courses (MOOCs), for example, if they be-

\section{Members of the committee}

Members of the ACRL Research Planning and Review Committee: Cheryl Middleton, chair, is associate university librarian for learning engagement at Oregon State University Libraries \& Press, e-mail: cheryl. middleton@oregonstate.edu; Wayne BivensTatum is philosophy and religion librarian at Princeton University, e-mail: rbivens@ princeton.edu; Beth Blanton-Kent is librarian for physical sciences at the University of Virginia, e-mail: blanton@virginia.edu; Heidi Steiner Burkhardt is head of digital services at Norwich University, e-mail: hmsteiner@gmail.com; Ellen Carey is librarian and instructor at Santa Barbara City College, e-mail: eecarey@sbcc.edu; Steven Carrico is acquisitions librarian at the University of Florida, e-mail: stecarr@uflib.ufl.edu; Jeanne Davidson is assistant university librarian for public services at Portland State University, e-mail: jeanne.davidson@pdx.edu; Chris Palazzolo is head of collection management and social sciences librarian and team leader at Emory University, e-mail: cpalazz@ emory.edu; Barbara Petersohn is liaison to the College of Education at the University of North Georgia, e-mail: barbara.petersohn@ ung.edu. 
come an established norm. There is yet no clear direction or timeline for how this will happen. While an estimated 500 MOOCs are being offered by more than 100 well-known universities, an acceptable, sustainable business model for their development and deployment is yet to emerge. Cathy Davidson notes that online delivery of instruction requires significant start-up investment and is an ongoing, labor-intensive enterprise. Higher education institutions have managed this burden in the past, but have not realized monetary gain from it. ${ }^{28}$

In this rapidly changing landscape, researchers will continue to require support and guidance from information professionals in navigating the requirements of open access and the development and promotion of OERs. In addition, librarians will need to stay informed and lead the way in collaborating with their institutions, publishers, organizations, and other academic libraries to develop new funding mechanisms and incentives to support faculty involvement in open access publishing.

\section{Student success}

An emphasis on student success outcomes and educational accountability by states, accrediting bodies, and individual institutions, as well as a shift in some states from public higher education funding based on enrollment to funding based on outcomes, such as retention and completion, have implications for academic libraries. These changes in the higher education environment necessitate that libraries engage across the institution to contribute broadly to student success as well as articulate and demonstrate their impact through assessment.

In some states, formal collaborations between librarians and other stakeholders are growing out of this emphasis on student success.

Funding, student success initiatives, and accreditation

While performance-based funding is nothing new, many have identified its resurgence in several states as a trend in higher education and new models have earned the term "Performance Funding 2.0." ${ }^{\prime 29}$ Numerous initiatives related to educational access and student success, such as Achieving the Dream ${ }^{30}$ and its Developmental Education Initiative, ${ }^{31}$ as well as many others, ${ }^{32}$ address a national college completion agenda identified by President Barack Obama in 2009 33 and form "a growing national movement focused on increasing student success and educational attainment." ${ }^{34}$ Many of these initiatives are aimed at community colleges, whose students amount to $45 \%$ of U.S. undergraduates. ${ }^{35}$ At the same time, accrediting bodies continue to expect colleges and universities as well as academic libraries to make the articulation and measurement of student learning outcomes a central part of their programmatic and departmental assessment activities.

\section{Libraries, student success, and demonstrat-} ing value

The increased focus on outcomes (e.g., student learning, retention, persistence, and completion) over inputs (e.g., enrollment,) and the ongoing emphasis on demonstrating these outcomes, will have an impact on academic libraries going forward. The academic library's connection to student success, persistence, and retention has already been discussed in the literature. $36,37,38,39,40,41,42,43$ The culture of increasing accountability for outcomes will require libraries to find better ways to document these connections. ${ }^{44}$

Programs such as ACRL's Assessment in Action: Academic Libraries and Student Success, ${ }^{45}$ part of the Value of Academic Libraries Initiative ${ }^{46}$ are designed to equip more librarians to do that. At the same time, collaborations between librarians, other academic support professionals, and faculty to develop student success initiatives both serve students and provide opportunities to demonstrate library value. ${ }^{47}$ Libraries must also align their missions with institutional and state student success missions, and focus resources on those students most in need of support. 
In California, community college librarians are involved in two statewide collaborative responses to the increased demands on academic institutions to demonstrate their value and focus on student success, persistence, and retention. The Council of Chief Librarians of the California Community Colleges recently developed a three-pronged strategy to achieve its goal to "strengthen the capacity of California community college libraries to support student success through the attainment of information literacy." ${ }^{48}$ The strategy includes the development of more consistent ways of teaching and measuring information literacy, the gathering and sharing of data documenting librarians' roles in supporting student learning outcomes on information literacy, and the formation of a statewide Information Literacy Advisory Committee.

California's 3CSN (California Community Colleges' Success Network) is an example of an effective collaboration between multiple stakeholders, including librarians. 3CSN fosters student success by training community college faculty and staff to network and "create communities of practice that will produce powerful learning and working across campuses." ${ }^{49}$ It encourages collaboration to develop coordinated student support efforts between libraries, peer assisted learning programs, and noncredit or basic skills level programs such as ESL and developmental English.

\section{Competency-based learning}

While the concept of awarding college credit for learning accomplished outside of the college classroom is not new, national incentives ${ }^{50,51}$ and state pressures on higher education institutions to perform, innovate, and reduce costs for students have ignited renewed interest in developing alternative models for assessing current and prior learning. The result is an increased emphasis on competency-based learning that can provide new opportunities for libraries to embed information literacy and research skills and strategies into the fabric of institutional curricula.
Various models are being used to accomplish documentation of student learning. Some models link competencies with credit hours while others explore "direct assessment" of student learning that is independent of student credit hours or other traditional metrics. The University of Wisconsin (UW) system, for example, offers the "UW flexible option" program ${ }^{52}$ that is self-paced and based on assessment of the mastery of skills, knowledge, and abilities, regardless of where the learning takes place. Other models, such as those at College for America (a subsidiary of Southern New Hampshire University) and Capella University, include options for programs independent of credit hours. ${ }^{53}$

Alternative options for documenting student learning like these require that institutions re-examine the basic measure of learning they intend to use, including the core outcomes they want for their graduates. Programs are based on desired program-level competencies that may or may not be associated with courses and credit hours. The process of articulating and defining program outcomes provides an opportunity for libraries to collaborate across the institution to further define fundamental information literacy concepts and skills as well as to explore new models for how students will be assessed in their achievement of these competencies.

\section{Altmetrics}

The expanding digital environment drives changes in the criteria for measuring the impact of research and scholarship. As the web matures and the researchers' works are referred to or published on the web, it is important to have a method for tracking the impact of their work in these new media. Altmetrics, short for alternative metrics, is a quickly developing methodology for measuring the impact of scholarly works and research published on the web. . $^{5,55,56,57,58}$ Proponents of altmetrics note that article citations and journal impact factors do not accurately measure the impact of web-based articles or the ensuing scholarly communication among scientists, scholars, and researchers. Altmet- 
rics, then, supplement the traditional means of measuring scholarly impact and the slower peer-review process. ${ }^{59}$

These new metrics are both a product and tool of the web, counting the standard social media outlets such as Tweets, Facebook "likes," and blog posts, as well as web activities, such as bookmarks and downloads. ${ }^{60}$ These metrics become increasingly important as researchers use web programs to organize and share articles with colleagues through Mendeley, Impact Story, and PLOS, or via article-sharing social network sites such as Academia.edu and ResearchGate.

Academic libraries have a long-standing tradition of collaborating with academic departments and their research faculty to demonstrate the impact of their scholarship through providing "scalable scholarly filters." Librarians anticipate continuing this role by providing access to, and instruction in, the appropriate use of altmetrics to promote the impact and value of the scholarship produced at their institutions in the global scholarly community. According to a NISO report on altmetrics, the large number of Google results mentioning both "Libguides" and "altmetrics" "indicate that libraries are already incorporating altmetrics information into resources for scholarly communication, impact, and citation management," but the report concludes that "the efficacy of these guides remains unknown." ${ }^{11}$

In 2013, NISO began an ambitious project to develop standards and practices for altmetrics. ${ }^{62}$ Whether standardized or not, "ambitious scholars have been including altmetrics on their curricula vitae for years." ${ }^{33}$ Potentially, altmetrics could have a bearing on the faculty evaluation and tenure process by providing review committees supplemental information about the social or interdisciplinary effect research is having on scholarly communities. ${ }^{64}$ Altmetrics could also potentially affect grant writing and the endowment of awards.

"If researchers can show that their recent research is generating a lot of interaction in the scholarly community, that information can provide an advantage in this tight funding environment." ${ }^{65}$

\section{Digital humanities}

"DH (digital humanities) can be understood as the place where traditional humanities research methodologies and media/digital technologies intersect." ${ }^{66}$ Academic libraries can play a key role in supporting humanities faculty in their research by creating partnerships and collaborations and helping to connect with other campus units needed to implement and carry out digital humanities research. With the rise in opportunities to involve undergraduate students in an authentic research experience, academic libraries can identify and organize resources and partner with humanities faculty to teach the skills necessary for effective humanities research.

How are academic libraries preparing to play a role in digital humanities? Some academic libraries have responded by creating new positions to support digital scholarship and others are focusing on partnering and collaborating with other units at their institutions to support this form of scholarship. To be successful partners and collaborators, academic librarians need to seek out and be aware of the digital humanities research that scholars at their institution are engaged in. ${ }^{67}$

Examples of successful academic library collaborations with digital humanities centers include the Maryland Institute for Technology in the Humanities at the University of Maryland-College Park, ${ }^{68}$ the Scholars' Lab at the University of Virginia, ${ }^{69}$ and the Digital Scholarship Commons at Emory University. ${ }^{70}$ Not all academic libraries need to establish centers for digital humanities in order to support teaching and research, and before doing so librarians should carefully consider the culture and environment of their institutions. $^{71}$

For those academic libraries exploring digital humanities and seeking effective ways to support their institutions, the ACRL series "Keeping Up With..." offers a detailed list of resources and information to consider. ${ }^{72}$ For more information and examples of academic library partnerships and collaborations, the Association of Research Libraries (ARL) has 
published an ARL SPEC 326 kit devoted to topic of digital humanities. ${ }^{73}$

Academic libraries are logical partners for digital humanities collaborations because they have already developed the skill sets necessary to sustain and preserve a digital archive. ${ }^{74}$ Through experiences gained creating digital repositories, working with faculty to manage federally funded research, and creating metadata and organizational schema for unique collections and resources, academic libraries can play a key role by partnering and collaborating with humanities scholars in digital humanities projects.

\section{Notes}

1. Institute for Advanced Analytics, North Carolina State University, http://analytics. ncsu.edu/.

2. Data Mining and Applications Graduate Certificate, Stanford University, http://scpd. stanford.edu/.

3. Certificate in Data Science, iSchool, Syracuse University, http://ischool.syr.edu /future/cas/datascience.aspx.

4. Master of Information and Data Science, Berkeley School of Information, http:// datascience.berkeley.edu/.

5. FigShare, http://figshare.com/.

6. Hollie White, "Examining Scientific Vocabulary: Mapping Controlled Vocabularies with Free Text Keywords," Cataloging E Classification Quarterly 51, no. 6: 65574 .

7. BioMedCentral, http://blogs . biomedcentral.com/bmcblog/2013/08/21 /opening-up-the-data-an-update-to-biomed -centrals-copyright-and-license-agreement/.

8. PLOS, www.PLOS.org/update-on-PLOS -data-policy.

9. Richard Van Noorden, Nature, "Elsevier opens its papers to text-mining," http://www. nature.com/news/elsevier-opens-its-papers-to -text-mining-1.14659.

10. OpenRefine, http://openrefine.org/.

11. Pew Research Center, January, 2014, "EReading Rises as Device Ownership Jumps," http://pewinternet.org/Reports/2014/E -Reading-Update.aspx. p.4.
12. Eden Dahlstrom, "ECAR Study on Undergraduate Students and Information Technology 2013," EDUCASE: Center for Applied Research (September), https:// net.educause.edu/ir/library/pdf/ERS1302 /ERS1302.pdf, p.29.

13. New Media Consortium, "Horizon Report: 2014 Higher Education Edition," www.nmc.org/pdf/2014-nmc-horizon-report -he-EN.pdf.

14. http://dartmouth.edu/.

15. http://www.earlham.edu.

16. http://umich.edu/.

17. http://gvsu.edu/library/.

18. http://search.library.utoronto.ca/index.

19. http://library.princeton.edu/.

20. http://speccoll.library.arizona.edu/.

21. http://www.oclc.org/go/en /worldcat-discovery.html.

22. ARL-SPARC provides an excellent round up of open access legislation at http:// www.sparc.arl.org/advocacy/national. For more information, see http://www.oacompact.org/compact/. As an example, see http:// guides.library.umass.edu/oer.

23. http://www.sparc.arl.org/COAPI.

24. http://library.duke.edu/research /openaccess/cope.

25. http://oregonstate.edu/ua/ncs /archives/2014/feb/osu-open-textbook -initiative-aims-reduce-student-costs -enhance-learning.

26. http://www.geneseo.edu/news _events/geneseo-receives-grant-continue -open-suny-textbook-initiative.

27. http://www.knowledgeunlatched.org /about/how-it-works/.

28. "Advice for Middle-Age Seekers of MOOCs, Part 2," The New York Times (September 11, 2013), http://www.nytimes. com/2013/09/11/booming/advice-for-middle -age-seekers-of-moocs-part-2.html.

29. M. M. D’Amico, J. N. Friedel, S. G. Katsinas, and Z. M. Thornton, "Current developments in community college performance funding," Community College Journal of Research \& Practice, 38 (2/3), 231-41.

30. http://www.achievingthedream.org/. 31. http://www.deionline.org/. 
32. http://www.aacc.nche.edu/About /completionchallenge/Pages/national _initiatives.aspx.

33. http://www.whitehouse.gov/blog /Investing-in-Education-The-American |Graduation-Initiative.

34. A. Russell, "American Association of State Colleges and Universities Higher Education Policy Brief: A Guide to Major U.S. College Completion Initiatives," http://www.aascu.org/policy/publications /policymatters/2011/collegecompletion.pdf.

35. American Association of Community Colleges, "2014 Fact Sheet," http:// www.aacc.nche.edu/AboutCC/Documents /Facts14_Data_R2.pdf.

36. S. Bell, "Keeping Them Enrolled: How Academic Libraries Contribute to Student Retention," Library Issues: Briefings for Faculty and Administrators, http://www. libraryissues.com/sub/PDF2901Sep2008.pdf.

37. M. Emmons, and F. C. Wilkinson, "The academic library impact on student persistence," College \& Research Libraries, 72(2), 128-49.

38. D. Rodriguez, "Understanding library impacts on student learning." In the Library with the Lead Pipe, http://www.inthelibrarywiththeleadpipe.org/2011/understandinglibrary-impacts-on-student-learning/.

39. M. Bowles-Terry, "Library instruction and academic success: A mixed-methods assessment of a library instruction program," Evidence Based Library and Information Practice 7(1). 82-95. http://wigan-ojs.library.ualberta.ca/index.php /EBLIP/article/view/12373.

40. K. M. Soria, J. Fransen, and S. Nackerud, "Library use and undergraduate student outcomes: New evidence for students' retention and academic success," Portal: Libraries And The Academy, 13(2), 147-64.

41. G. Haddow, "Academic library use and student retention: A quantitative analysis," Library \& Information Science Research, 35(2), 127-36.

42. B. Teske, M. DiCarlo and D. Cahoy, "Libraries and student persistence at southern colleges and universities," Reference Services Review, 41(2), 266-79.
43. M. A. Hubbard and A. T. Loos, "Academic library participation in recruitment and retention initiatives," Reference Services Review, 41(2), 157-181.

44. M. Oakleaf, "Executive summary," Value of Academic Libraries: A Comprehensive Research Review and Report, http://www. ala.org/acrl/sites/ala.org.acrl/files/content /issues/value/val_summary.pdf.

45. http://www.ala.org/acrl/AiA.

46. http://www.acrl.ala.org/value/.

47. J. E. Sanabria, "The library as an academic partner in student retention and graduation: The library's collaboration with the Freshman Year Seminar initiative at the Bronx Community College," Collaborative Librarianship, 5(2), 94-100.

48. Council of Chief Librarians, "20132014 Action Plan,” http://www.cclccc.org /documents/2013/CCL-2013-2015-ActionPlan.pdf.

49. http://3csn.org/about/theory-of -change/.

50. "FACT SHEET on the President's Plan to Make College More Affordable: A Better Bargain for the Middle Class," August 22, 2013.

51. David A. Bergeron, "Applying for Title IV Eligibility for Direct Assessment (Competency-Based) Programs," March 19, 2013, http://ifap.ed.gov/dpcletters/GEN1310. html.

52. "Competency-Based Education: What It Is, How It's Different and Why It Matters to You," January 24, 2014, http://flex.wisconsin. edu/competency-based-education-what-it-is -how-its-different-and-why-it-matters-to-you/.

53. Paul Fain, "Taking the Direct Path," Inside Higher Ed, February 21, 2014, http:// www.insidehighered.com/news/2014/02/21 /direct-assessment-and-feds-take-competency -based-education\#sthash.EeXOGCiH.dpbs.

54. Finbar Galligan and Sharon DyasCorreia, "Altemetrics: Rethinking the way we measure," Serials Review 39, no. 1: 56-61.

55. Jason Priem, Paul Groth, and Dario Taraborelli, "The altmetrics collection," PLOS ONE (November 01, 2012), DOI: 10.1371 /journal.pone.0048753. 
56. Robin Chin Roemer and Rachel Borchadt, "From bibliometrics to altmetrics: A changing scholarly landscape," CERL News 73, no. 10: 596-600.

57. Mike Thelwall, Stefanie Haustein, Vincent Lariviere, and Cassidy R. Sugimoto, "Do altmetrics work? Twitter and ten other social web," PLOS ONE (May 28, 2013).

58. Virginia Wilson, "Research methods: Altmetrics," Evidence Based Library and Information Practice 8, no. 1: 126-28. https:// ejournals.library.ualberta.ca/index.php /EBLIP/article/view/18900/14822.

59. Jason Priem, Dario Taraborelli, Paul Groth, and Cameron Neylon, "Altmetrics: A Manifesto," (v.1.0), 26 October 2010. Revised, (v 1.01), September 28, 2011, http://altmetrics. org/manifesto.

60. Irene L. Travis, "Editor's Desktop," Bulletin of the Association for Information Science and Technology 39, no. 4 (April/ May 2013): 2, http://www.asis.org/Bulletin /Apr-13/Bulletin_AprMay13_Final.pdf.

61. http://www.niso.org/apps/group _public/download.php/11272/FE_Roemer _Borchardt_Institutional_Altmetrics _isqv25no2.pdf.

62. NISO, "NISO to develop standards, practices for altmetrics," Advanced Technology Libraries 42, no. 8 (August 2013): 5 , http://site.ebrary.com/pub/atl/docDetail. action?docID=10798065\&page $=1$.

63. Heather Piwowar, and Jason Priem, "The power of altmetrics on a CV," Bulletin of the Association for Information Science and Technology 39 no. 4 (April/May 2013): 10, http://www.asis.org/Bulletin/Apr-13 /AprMay13_Piwowar_Priem.html.

64. Stacy Konkiel and Dave Scherer, "New opportunities for repositories in the age of altmetrics," Bulletin of the Association for Information Science and Technology 39 no. 4 (April/May 2013): 22-25.

65. Mike Buschman, Mike and Andrea Michalek, "Are alternative metrics still alternative?" Bulletin of the Association for Information Science and Technology39, no. 4 (April/May 2013): 35-39, http://www. asis.org/Bulletin/Apr-13/AprMay13_Buschman _Michalek.html.
66. Jennifer L. Adams, and Kevin B. Gunn, "Keeping Up With...Digital Humanities," American Library Association: ACRL, April 2013, http://www.ala.org/acrl /publications/keeping_up_with/digital _humanities.

67. Donald J. Waters, "An Overview of the Digital Humanities," Research Library Issues: A Report from ARL, CNI, and SPARC, no. 284 (2013): 3-11. http://publications.arl. org/rli284/.

68. http://mith.umd.edu/.

69. http://www.scholarslab.org/about/.

70. http://digitalscholarship.emory.edu/.

71. Jennifer Schaffner and Ricky Erway, Does Every Research Library Need a Digital Humanities Center? (Dublin, Ohio: OCLC Research), http://www.oclc.org/content /dam/research/publications/library/2014 /oclcresearch-digital-humanities-center-2014. pdf.

72. Jennifer L. Adams and Kevin B. Gunn, "Keeping Up With ... Digital Humanities," American Library Association: ACRL, April 2013, http://www.ala.org/acrl/publications /keeping_up_with/digital_humanities.

73. Tim Bryson, Miriam Posner, Alain St. Pierre, and Stewart Varner, "SPEC Kit 326: Digital Humanities" (November 2011) SPEC Kit 326: Digital Humanities (November 2011), Association of Research Libraries, 2011, web, April 26, 2014, http://publications.arl.org /Digital-Humanities-SPEC-Kit-326/.

74. W. A. Kretzschmar and W. Gray Potter, "Library Collaboration with Large Digital Humanities Projects," Literary and Linguistic Computing 25.4 (2010): 439-45. n

\section{C\&RL News RSS}

Cover art, article links, and other valuable information from CERL News is available by subscribing to our RSS feed.

Point your Web browser to feeds. feedburner.com/candrlnews, and add our feed to your favorite feed reader. 